Araştırma Makalesi

\title{
İdeolojik Bir Söylem Olarak Slogan Üzerine Düşünmek: Türkiye'de Mart 2019 Yerel Seçimlerinde Kullanılan Parti Sloganları Üzerine Kıyaslayıcı Bir Analiz
}

\author{
Mikail Batu (Doç. Dr.)
}

iD Ege Üniversitesi İletişim Fakültesi mikail.batu@ege.edu.tr

Akan Yanık (Doç. Dr.)

iD Adnan Menderes Üniversitesi Atça Meslek Yüksekokulu akanyanik@gmail.com

Onur Tos (Öğr. Gör.)

iD Tarsus Üniversitesi Meslek Yüksekokulu onurtos@tarsus.edu.tr

Bașvuru Tarihi: 09.10.2020

Yayına Kabul Tarihi: 11.01.2021

Yayınlanma Tarihi: 29.01.2021

https://doi.org/10.17680/erciyesiletisim. 808380

\section{Öz}

Seçmen desteğinde önemli rol oynayan ideolojiler, belli amaçlar çerçevesinde oluşturulmuş sloganlar yoluyla halka aktarılmaktadır. Partilerin ideolojilerini ve farklı disiplinlerin ikna etme tekniklerini temel alan sloganlar, seçmenin istenen yönde oy kullanma davranışını gerçekleştirmesine etkide bulunmaktadır. Diğer bir ifadeyle sloganlar, kitle iletişim araçları, siyasal reklam ilanları ve açık hava platformları gibi farklı ortamlarda seçmenin karşısına çıkmakta ve hedef kitlenin algısının yönetilmesinde önemli rol oynamaktadır. Siyasi partiler, tematik kampanyalarını yaratıcı sloganlarla etkili mesajlar haline getirerek rakiplerinden farklılaşmakta ve seçmeni etkilemektedir. $\mathrm{Bu}$ çalışmanın amacı, Mart 2019 Türkiye yerel seçimlerinde Cumhur ve Millet ittifaklarının kullandıkları ideolojik sloganlara odaklanarak kıyaslayıcı bir analiz gerçekleştirmektir. Araştırmanın temel sorunsalı, ittifakların kullandıkları sloganlarda hangi kavramların kesiştiğini ve farklılık gösterdiğini ortaya koymaktır. Değerlendirmede sloganlarda gönül ve umut kodlarının öne çıktığı, sistemin verilen hizmet üzerinden anlatıldığı, içinde bulunulan şehrin sıklıkla vurgulandığı, zaman olarak da geleceğin daha çok belirtildiği görülmüştür. Ayrıca ittifakların seçmenlerinin algısına, kendilerinin belirledikleri söylem odağında seslendiği, kendi partilerinin üzerinde durdukları ve diğer partilerden farklılık gösteren temaların özellikle mevcut ideolojilerini yansıttığı sonucuna varılmıștır.

Anahtar Kelimeler: Halkla İlişkiler, İdeoloji, Seçim Sloganı, Cumhur İttifakı, Millet İttifakı. 


\title{
Thinking on the Slogan as an Ideological Discourse: A Comparative Analysis on the Party Slogans Used in the March 2019 Local Elections in Turkey
}

\author{
Mikail Batu (Assoc. Prof. Dr.) \\ Ege University Faculty of Communication \\ mikail.batu@ege.edu.tr
}

Akan Yanık (Assoc. Prof. Dr.)

iD Adnan Menderes University Atça Vocational School akanyanik@gmail.com

Onur Tos (Lect.)

iD Tarsus University Vocational School

onurtos@tarsus.edu.tr

Date Received: 09.10.2020

Date Accepted: 11.01.2021

Date Published: 29.01.2021

https://doi.org/10.17680/erciyesiletisim.808380

\begin{abstract}
Ideologies, which play a crucial role in voter support, are conveyed to the public via slogans created for specific goals. Slogans, which are based on the ideologies of the parties and the persuasion techniques of different disciplines, influence the voting behaviors of voters in the desired direction. Political parties try to be different from their rivals by creating thematic campaigns to form messages with creative slogans and affect voter. The aim of this study is to make a comparative analysis focusing on the ideological slogans used by People's Alliance and Nation Alliance in local-elections of 2019 in Turkey. The main problem of the study is to reveal the similar and different part of notions in the slogans used by the Alliances. It was seen in the evaluation that the codes, heart and hope, became prominent notions, the system was explained through the political service promises, the city was frequently emphasized, and the concept, future, was mentioned. In addition, it was concluded that the alliances influenced the perception of their voters with the focus of their discourse, and the themes, which were mentioned by the parties and differed from the other parties, reflected current ideologies of the parties in the election.
\end{abstract}

Keywords: Public Relations, Ideology, Election Slogan, People’s Alliance, Nation Alliance. 


\section{Giriş}

Toplum içerisinde sisteme yönelik yapı, bireyin bilgi yönetim kapasitesini diğer bir ifadeyle kendi bașına anlayabilme, açıklayabilme, ilişkiler kurabilme ve savunabilme kapasitesini aşabilmektedir. Siyasal iletişimde de gerçeklikleri aktarmaktan ziyade bu gerçekliklerle kitleleri sürükleme ve öğretilmiş eylemlerle yeni durumlar yaratma amacı devreye girdiğinde (Charaudeau ve Maingueneau, 2002) gerçeklik bireyin bilgi yönetim kapasitesini zorlayabilecek çok daha karmaşık bir forma dönüşmektedir. Örneğin, sosyal yapı önderleri, iktidarlar, siyasiler ve din adamları çağlar boyunca doğaya, topluma, yaşama, yönetime ve Tanrı'ya ilişkin soruların yanıtlarını özel olarak kodlayarak ortak değere dönüștürme gereği görmüş ve hazır ideolojik bilgiler olarak insanlara sunmuştur (Sharkansky, 2002). Söylemlerle zenginleştirilen bu hazır toplu bilgiler, var olanı açıklamaya çalışan bir enformasyon aktarımından öte, ideolojik kaygıyla yaşamı yeniden şekillendirmeye çalışan, doktrinler veya öğretilerin uzantıları gibidir (Power, 2016). Bireyin özellikle ait olma ve kontrol etme ihtiyacından beslenen ideolojiler (Eagleton, 2004), günümüzde siyasal iletişim üzerinden kendini baskın olarak hissettirmekte ve seçim dönemlerinde siyasi partilerin yaratıcı söylemleri üzerinden seçmenlere etki etmektedir. Ayrıca çeşitli ideolojiler altında politikalar üreten siyasi partiler, kendilerini ifade etmek ve taraftar kazanabilmek için siyasal iletişimin tüm fırsatlarını etkin olarak kullanmaktadır. Çünkü demokratik ülkelerde ideolojileri ve politikaları hayata geçirebilmenin tek yolu, sayısal anlamda diğer partilerden daha fazla seçmen kitlesinin desteğini almak ve iktidara gelmektir. Bu amaçla partiler, ideolojilerini söylemler aracılığıyla gerçek dünyanın vaatleriyle güçlendirmekte, ikna ettikleri kitlelerle ideolojilerine meşruiyet kazandırmakta ve yaratıcı sloganlarla geniş kitleleri sürüklemeye çalışmaktadır. Sosyolojik ve politik tüm gerçekliklerin ideolojik söylemlerle dönüştürüldüğü (Drucker, 1974), bu ortamda bireyler, kendi gerçeklikleriyle de tutarlı ideolojik bilgileri kabul ederek gerçeklerin dayattığı risk algılarını yönetme eğilimine girmektedir. Fakat yaşamı kolaylaştırmayı vaat eden ve insanlığın eline tutuşturulmuş yol haritaları olarak gösterilen ideolojik söylemler, bireylerin toplumsal konumlarını tanımlayan, gerçekliğe olan bakış açısına etki eden, toplumsal yapılarla etkileşim biçimlerini dönüştüren, itaat ve istikrara dair eylemlere karşı düşüncelerini değiştiren bir bilinçaltı tasarımı olarak ele alınabilir. İdeolojilerin, bireylerin dünyayı anlama, anlamlandırma ve kontrol etme gibi tercihlerini belirlediği ve gelecekteki eylemlerini veya eylemsizliklerini etkilediği göz önüne alınırsa bu bilinçaltı tasarımların doğasının keşfedilmesi ve analiz edilmesi büyük önem taşımaktadır. Üzerinde çok fazla söz söylenmiş fakat anlaşmaya varılmamış (Mardin, 2010, s. 24) ideolojik söylemin, Zizek (2011, s. 44) tarafından ifade edildiği üzere tıpkı boş bir kutu gibi içini dolduranlar ile şekillenmesi, bu konuda sürekli güncellenen analizlere ve araştırmalara ihtiyaç olduğunu göstermektedir. Bu çalışmada da ideolojik söylemin siyasal iletişimde araştırılmaya ve analiz edilmeye değer çok önemli bir alan olduğu düşünülmüş ve partilerin söylemleri ekseninde geliştirdikleri sloganlarına kıyaslayıcı bir analizle odaklanılmıştır.

\section{İdeolojinin Tarihi Arka Planı ve Söylemlerdeki Dilin Dönüşümü}

İdeoloji, 1796 yılında Destutt de Tracy tarafından, düşünceleri, inanışları veya doktrinleri (fr. idée) bilimsel bir şekilde tahlil eden (fr. logie) bir kavram olarak ortaya çıkmış (Althusser, 2003, s. 75) ve 1835 yılında Fransız Akademisi tarafından çıkarılan sözlügün üçüncü baskısında kendine yer bulmuştur (Meriç, 1996). Fakat kavramın anlamına ilişkin bilgi faaliyetlerinin aslında çok daha geçmiş yıllardan beri uygulandığı bilinmektedir. Pratkanis ve Aronson (2008, s. 12) Mayalara ait abideler ve yazitlarda, kralların güçlü ve abartılı betimlemelerinin imaj ve sembol kavramları ışığında değerlendirilmesi 
gerektiğini aktarmakta ve bu ayrıntıların bir tür ideolojik söylem ve propaganda yöntemi taşıdığını vurgulamaktadır. Dünyanın en eski yazılı eserlerinden olan Orhun Yazıtları'nda da benzer betimlemeler olduğu göz önüne alınırsa ideoloji ve propagandanın çok daha eskilere uzandığı iddia edilebilir. Ansiklopedik tanımlar ışığında ideoloji kavramı, düşünceleri bilimsel olarak tahlil etme gibi yansız ve yalnızca betimleyici bir eylem gibi görünse de tarihsel örnek olaylar ışığında söylem yaratıcılarının yanlı ve baskın eylemleri olarak öne çıkmaktadır. Yanlı ve baskın söylemler dizimi (sentagmatik) ve dizgisi (paradigmatik) olan ideoloji (Rıfat, 2013), altyapı-üstyapı metaforundan hegemonyaya, dil çözümlemelerinden söylem analizlerine uzanan karmaşık tarihi serüven içinde (Örs, 2009) her çağda olumlu veya olumsuz olarak anılmaktadır. Dolayısıyla kavramın sahip olduğu tarihi serüvenin kendisi, başta söylem olmak üzere, kavramın yapısındaki tüm unsurları etkilediğinden, ideoloji kavramı kadar ideolojinin tarihi serüvenini bilmek de büyük önem taşımaktadır.

İdeoloji kavramı Fransız İhtilali döneminde Batı dünyası tarafından üretilen (Drucker, 1974; Mardin, 2010) ve on dokuzuncu yüzyll sonuna kadar popülerliği korunan bir kavram olmasına rağmen yirminci yüzyılda yine Batı tarafından olumsuz bir kavram olarak dikte edilmiş, sert şekilde eleştirilmiş ve tartışılmıştır. Örneğin on dokuzuncu yüzyıla kadar ideoloji kavramı, temel bir öğreti ve ilerici bir aktivist düşünce biçimi olarak görülürken (Carver, 1995); yirminci yüzyılda "bütün bilgileri ve diyalogları bir araya getiren ve dizgileyen bir canavar" (Barthes, 1996, s. 104) olarak betimlenmiştir. $\mathrm{Bu}$ çatışma ve tartışma, ideoloji ile ilgilenenleri öven ideolojist (fr. idéologiste) ve onları aşağılayan ideolog (fr. idéologue) kavramları üzerinden alevlenmiş (Meriç, 1996) ve karşıt kavramların doğmasına neden olmuștur. Özellikle Napolyon'un ideoloji ile ilgilenenleri her ortamda aşağılaması ve "metafizikçi faydasız boş işler uzmanı" olarak adlandırmasına karşı konunun uzmanları da Napolyon ile dalga geçen "idéophobe" lakabı ile karşılık vermiştir (Yıldız ve Günay, 2011). Marksist "halklara özgürlük" sloganı ışı̆̆ında sömürgecilikten kurtulma dalgasıyla yükselişe geçen ideoloji kavramı (Mardin, 2010) özellikle ikinci dünya savaşından sonra ciddi bir kırılma yaşamıştır. Bu dönemden sonra sınıfsal ayrım temelinde inşa edilen Marksist ideolojiden kurtulma akımı içinde ideoloji kavramının geneline karşı hızlı bir cephe oluşmuş ve kavram, ideoloji-sonrası kültür kuramları gölgesinde ele alınarak eleştirilmiştir (Çelik, 2005). Özellikle Batı dünyası, Marksist söylemi hatırlatan ideoloji kavramını duymaktansa, aynı tartışmayı dile getiren kültür kuramlarını kullanmayı tercih etmiş ve 80'lerle birlikte ideoloji kavramı yerini kültür kavramına bırakmıștır (Yıldız ve Günay, 2011). Eagleton (2004) tarafından "şeyleri doğallaştırmaktan şeyleri kültürleştirmeye" giden bu eksen kaymasında ideolojinin ve söylemin dönüşümünü anlamak için, Batı güdümünde tasarlanan yenidünya yaşam tarzına meşruiyet kazandıran kültür kuramlarına özellikle odaklanılması gerekmektedir. Çünkü ancak 80’lerde net şekilde hissedilen bu dönüşüm bir yılda gerçekleşmemiş, özellikle 70'li yıllardaki sinema, televizyon, dergi, müzik ve moda gibi kültür endüstrileriyle (McLuhan, 2002) aşamalı şekilde yaratılmıștır. Böylece kültür endüstrisinin aygıt ve medya yapılarıyla sunulan işaretler ve göstergeler, zamanla bir dil olarak gündelik yaşamın dili haline gelmiştir. İlk bakışta toplumsal dil ve eylemlerdeki bu hızlı dönüşüm hareketi açık bir ideoloji faaliyeti gibi görünmesine rağmen aslında ideoloji ötesi bir bilgi faaliyetidir. Bu nedenle sınıfların ve halkların farklılıklarını düşünceleri ekseninde vurgulayan ideoloji kavramı ile Batı dünyasının homojen ideal yenidünya düşüncesinden beslenen kültür kuramları çatışmaya başlamış ve ideoloji kavramı, radikal bir eylem olarak ayrışmıştır. Çünkü ideoloji kavramı, farklı düşünce ve doktrine bağlı toplulukları "kendi özel topluluk yapıları içinde kabul ederek" 
sert bir mücadele ve etkileyici söylemlerle etkilemeye çalışırken; ideoloji karşıtı kültür kuramları, farklı topluluk yapılarına hassasiyet göstermeksizin onları bir kümede toplamak için yumuşak fakat aksiyolojiden beslenen ötekileştirici bir dille etkilemeye çalışmaktadır. Dolayısıyla kültür kuramlarında her ne kadar "kültür" vurgusu öne çıksa da bu vurgu tüm kültürlere saygı gösteren ve seslenen özel bir dilin geliștirilmesini değil, tek bir kültür ve yaşam anlayışını yaratma idealini işaret etmektedir. Bu sebeple özellikle 90'lı yıllardan sonra ortak değer, ortak anlam ve ortak temsil (Bourdieu, 2000; Charaudeau ve Maingueneau, 2002 (Charaudeau ve Maingueneau, 2002; Eagleton, 2005) gibi yenidünya görünüşünü kuran türdeş (fr. homogène) bir toplumsal inanç formu ideali (Sapiro, 2007) yükselişe geçmiştir. Bahsedilen tarihsel arka planın bu çalışmayla olan ilişkisi, ideolojiden kültür kuramlarına doğru eksen kayması söylemlerin de tasarımını ve vurgularını dönüştürmüştür. Bu kısa arka planda sunulduğu üzere, ideoloji kavramına karşı çıkışları anlayabilmek için Batı dünyasının yaşadığı önemli travmalar olan Fransız İhtilali, 19. yüzyıl sömürgeciliğe karşı milliyetçi eylemler ve ikinci dünya savaşı öncesi siyasi hareketlerin derinlemesine analiz edilmesi gerekmektedir. Bu analiz sonucunda ancak siyasal iletişimdeki söylemlerin dili ve arka planı anlaşılabilir ve hem göstergeler hem de söylemler doğru şekilde çözümlenebilir. Aksi halde çağın dikte ettiği buğulu ideolojik gözlüklerle görülmesi gerekenler değil gösterilenler öne çıkmakta (Zizek, 2011) ve bilimsel çözümlemeler yanlış ve kısır tartışmaları yaratmaktadır.

\section{Söylemler ve Sloganlar Işığında Siyasal İletişim}

İdeoloji kavramının tarihi art alanı ve çıktıları en çok söylemler üzerinde etkili olmuştur. Çünkü en sade biçimiyle ideoloji ile söylem arasındaki ilişki insan ile dil arasındaki ilişki gibidir. İçi soyut düşüncelerle dolu ideoloji kavramının yaşayan bir gerçeğe dönüşme süreci ancak söylem denilen özel dizgilerle konuşmasıyla başlamaktadır. Böylece ideoloji, bilinen gerçekliğin ötesinde öğretilmiş eylemler oluşturmakta ve bu eylemlerle yeni bir durum yaratılabilmektedir. Bir duruma, konuya, kişiye, nesneye veya olguya nitelik kazandırma çabası olan ideoloji (Krysinski \& Krysinski, 1981, s. 32), zamanın gerçeklerini gösterge ve simgeleștirmelerle dönüştürmekte ve söylem denilen sürükleyici ve yaratıcı dizgilerle hedef kitlenin zihnindeki her türlü değerin güncellenmiş konumunu belirginleştirmektedir (Greimas, 1979, s. 180). İdeoloji ile söylem arasındaki ilişkide en dikkat çekici unsur, söylemin bir değişkeni ve ideolojinin temel kabulleri olan aksiyolojinin (axiologie) zaman içinde bir paradoks yaratmasıdır. Örneğin, başta radikal veya farklı bir fikir olarak beliren ideoloji, söylemlerdeki etik ve estetik adı verilen aksiyoloji ile geniş kitlelerin benimsemesini kolaylaştırıcı kabuller sunmaktadır. Fakat ideolojik hedeflere ulaşıldıktan sonra aynı aksiyolojik kabuller, dogmatik bir inanış haline gelen ideolojik yapıyla çelişmeye başlamaktadır. Bunun sebebi, amaçlanan ideolojik koşul ve duruma ulaşıldığı andan itibaren farklı ideolojik öznelere karşı savunmaya geçilmesidir. Bu savunma aşamasında giderek katılaşan ve dogmatik hale gelen ideoloji, liderleri tarafından, kendi temelini oluşturan etik ve estetik olarak adlandırılan aksiyolojik kabullerden koparılmakta, çıkarlar doğrultusunda sürekli olarak değiştirilmekte ve sonuç olarak "yeni" kelimesinin sıklıkla zikredildiği bir ideolojik "şeyleşme süreci" (Lukacs, 2006) başlamaktadır. George Orwell, Stalin yönetimini eleştiren Hayvan Çiftliği (1945) adlı romanında ideolojik dönüşümü, yenileşmeyi ve şeyleşmeyi hayvanlar devrimi ve domuzlar üzerinden sanatsal bir şekilde aktarabilmiştir. Bu şeyleşme sürecinin yarattığı devinim, gerçek hayatta siyasal iletişim kapsamındaki söylem ve slogan analizlerinde net şekilde görülebilir.

Siyasal iletişimin en etkili ve doğrudan iletişim yöntemi olan sloganlar (Butler ve 
Collins, 1994) yalnızca seçmenin dikkatini çeken, rakiplerinden ayrıştıran ve geniş kitlelerin desteğini sağlayan tasarımlar (Sharkansky, 2002) değil; hedef kitleyle özel bağlar kuran (Cone, 2006) ve bilinçaltına hitap eden örtük formüllerdir. Siyasi partiler, daha fazla sayıda seçmeni peşinden sürükleyebilmek için söylemlerini yalın ve örtük şekilde kodlanmış sloganlarla içselleştirmektedir. Böylece hem üye ve destekçilerinin tutumlarını pekiştirmekte hem de kararsız ve karşıt tutumlu seçmenlerin ikna edilmesini sağlamaktadır (Özkan, 2004). Bu noktada, kelime kökeni "sluagh-ghairm" yani savaş çığlığı olan (Öztürk, 2014) slogan tasarımının ilk kuralı yalın ve kısa olmasıdır. Literatürde yalın sloganların iletişim süreçlerini kolaylaştırdığı vurgusu öne çıksa da (Lanning ve Michaels, 2000; Cone, 2006) aslında önemli olan insanlar için yalın bir sloganın çok daha zeki bir tasarım olarak algılanmasıdır (Johnson, 2013; Rivkin ve Sutherland, 2011). Benzer şekilde, Amerikalı ünlü gazeteci ve dil uzmanı William Lewis, Safire, kısa, kafiyeli, ritim içeren veya ses uyumu gösteren sloganların en başarılı seçim sloganları olduğunu aktarmaktadır (Power, 2016). Fakat insan zihninin yoğun enformasyon bombardımanı altında olduğu ve dikkat çekmenin ekonomik bir değer olarak yükseldiği modern çağın koşulları düşünüldügünnde (Davenport ve Beck, 2010), başarılı yalın sloganlar tasarlamak giderek zor hale gelmektedir. Seçim süreci gibi zorlu koşullarda zekice hazırlanmış yalın sloganlar, geniş kitlelerin hızlı bir şekilde ilgisini çekebilmekte ve onları sürükleyebilmektedir. Örneğin, siyasal iletişim alanında 1924 ABD Başkanlık Seçimlerinde hiçbir şans tanınmamasına rağmen Calvin Coolidge'ın politikacıların çok fazla konuşup iş yapmadığını öne çıkaran "Silent Cal" ve "Keep Cool" sloganları dönemin fenomeni haline gelmiş ve başkanlığı kazandırmıştır. 1952 yılında ise Dwight Eisenhower'ın "I Like Ike" adlı kafiyeli ve yalın sloganı başarılı olabilmiştir. Barack Obama'nın "Change" ve "Hope" sloganları ve Donald Trump'ın "Make America Great Again" adlı sloganı da başarılı yalın sloganlar olarak gösterilebilir. ABD dışında İngiliz Muhafazakâr Partisinden Margaret Thatcher'ın 1979 genel seçimlerinde kullandığı "Labour isn't working" yani işçiler çalışmıyor sloganı hem iktidar olan İşçi Partisini eleştiren hem de dönemin en önemli sorunu olan işsizliği vurgulayan yalın ve zekice bir slogan olarak geniş kitleleri sürükleyebilmiştir. Türkiye'de ise yalın sloganların başarısını gösteren en önemli örnek Demokrat Partinin 1950 genel seçimlerinde kullandığı "Yeter, Söz Milletindir!" adlı sloganıdır. Sloganlar tek başlarına seçim kazandıramaz. Seçim kazandıran başarılı bir slogan, dönemin koşullarını ve sorunlarını çok iyi öne çıkaran bir iç mantığa ve bunu en doğru şekilde aktaran dilsel bir tasarıma sahip olmalıdır. Calvin Coolidge kendi dönemindeki çok konuşan ve güvenilmez siyasetçi gerçeğini, Obama yükselen değişim arzusunu, Trump büyük ABD hayalini, Thatcher işsizliği ve Adnan Menderes ise tek parti rejiminden duyulan rahatsızlığı öne çıkarmış ve zekice sloganlaştırmıştır. Dolayısıyla başarılı sloganlarla ilgili bir bakış geliştirmek gerekirse; sloganların dil yapısına ilişkin yönü dizimsel (sentagmatik) ve dizgisel (paradigmatik) (Yeygin, 2012; Gümüştekin, 2011; Berger, 1999) pratiklerle oluşturulurken, mantıksal yönü dönemin öne çıkan sorunlarının metaforik ve metonimik (Ryan ve Kellner, 2016) anlatımlarla dönüştürülmesinden meydana gelmektedir. Dönemin öne çıkan sorunları yapısal ve mantıksal dokunuşlarla özellikle belirtik (fr. explicite) bir formdan örtük (fr. implicite) bir bilinçaltı öğesine dönüştürülmektedir. Bunun nedeni, örtük aktarmanın veya sezinletmenin çoğu zaman açık söylemekten çok daha etkili olabilmesidir (Maingueneau, 2007). Benzer şekilde Althusser de ideolojilerin içselleştirilmesinin ancak söylem ve sloganların bilinçaltını harekete geçirmesiyle mümkün olacağını aktarmaktadır (Charaudeau ve Maingueneau, 2002).

$\mathrm{Bu}$ çalışma, ideolojinin tarihsel arka planı, ideolojik söylemlerdeki dilin dönüşümü 
ve başarılı slogan tasarımına yönelik literatür incelemesi ıșığında, Cumhur İttifakı ve Millet İttifakı'nın Mart 2019 yerel seçim dönemi boyunca kullandıkları sloganları analiz etmektedir. Çalışmanın amacı, ittifakların sloganlarıyla vurguladıkları söylemlerin ve etkilerinin kıyaslanmasıdır. Bu amaçla, söylem ve sloganlarda öne çıkan tema ve anahtar kelimeler özenle kodlanmış ve ittifakların yürüttükleri siyasal iletişimin geniş spektrumu kıyaslayıcı bir analizden geçirilmiştir.

\section{Yöntem}

\section{Araştırmanın Amacı ve Analiz Yöntemi}

Araştırmanın amacı Türkiye'de Mart 2019 yerel seçimlerinde partilerin 81 ilde kullandıkları sloganlarını ele alıp bu sloganlarda nelere yer verdiklerini saptamak ve TBMM çatısı altında oluşturulan Cumhur ve Millet İttifaklarının sloganlarını ideolojik çerçevede kıyaslamaktır. Sloganların incelenmesinde nitel analiz yöntemleri çerçevesinde ele alınan içerik analizi kullanılmıştır. İçerik analizi; aralarında etkileşim bulunan verilerin, ortak kavram ve tema altında birleştirilmesi ve okuyucunun anlayabileceği şekilde aktarılması yöntemidir (Yıldırım ve Şimşek, 2018). İçerik analizi metin çözümlemelerinde, ses kayıtlarının deşifre edilmesinde, film ve fotoğraf incelemelerinde, sosyal medya gibi platformda yer alan içeriklerin analizinde kullanılmaktadır. Bununla birlikte, politik kampanya dönemlerindeki siyasi söylemlerin analizi de içerik analizi yöntemiyle yapılabilmektedir (Yıldırım, 2015).

\section{Araştırmanın Soruları}

Araștırmanın ana sorusu 2019 yerel seçimlerinde Cumhur ve Millet İttifaklarının kullandıkları sloganlarda hangi kavramların kesiştiğini ve farklılık gösterdiğini ortaya koymaktır.

Araştırmanın alt soruları ise aşağıdadır:

- Ak Parti kullandığı sloganlarında en fazla vurguyu hangi temalar üzerinde yapmaktadir.

- Milliyetçi Hareket Partisi kullandığı sloganlarında en fazla vurguyu hangi temalar üzerinde yapmaktadır?

- Cumhuriyet Halk Partisi kullandığı sloganlarında en fazla vurguyu hangi temalar üzerinde yapmaktadır?

- İYİ Parti kullandığı sloganlarında en fazla vurguyu hangi temalar üzerinde yapmaktadır?

Tüm sloganlar, yukarıdaki sorular çerçevesinde teker teker değerlendirilmiş ve bulgular ile tartışma kısmında ele alınmıştır.

\section{Araştırmanın Evreni, Örneklemi ve Kısıtıılığı}

Çalışmanın evrenini, TBMM'de bulunan ve 31 Mart 2019 Yerel Seçimlerine katılmış tüm siyasi partilerin il belediye başkan adaylarının sloganları oluşturmaktadır. Çalışmanın örneklemini ise 31 Mart 2019 Yerel Seçimlerine katılan ve Cumhur ittifakı içinde yer alan Ak Parti, MHP ve Millet İttifakı içinde yer alan CHP, IYII Parti il belediye başkan adaylarının sloganları oluşturmaktadır. Bu kapsamda AK Partinin 159, MHP'nin 85 sloganı, CHP'nin 145 ve İYİ Partinin 103 sloganı, partilerin resmi web sitelerinden ve resmi sosyal ağlarından elde edilmiş ve değerlendirme altına alınmıștır. Çalıșmada 31 Mart 2019 Yerel Seçimlerine katılan ve ittifaklar içerisinde yer alan dört partinin sloganlarının ele alınması 
bir kısıtlılıktır. Ayrıca Partilerin yalnızca il belediye başkanlığı adaylarının sloganlarının ele alınması bir diğer kısıtlılıktır.

\section{Verilerin Analiz Süreci ve Bulgular}

Değerlendirilecek sloganlar adayların bağlı oldukları partilerin resmi web sitelerinden ve resmi sosyal ağlarından elde edilmiş ve sonrasında tüm sloganlar word dosyasında yazılı bir tablo haline getirilmiştir. Bu tablo, iki yazar tarafından ayrı ayrı Maxqda 2018 programında mx18 uzantılı formatla farklı bilgisayarlarda kaydedilmiştir. Daha sonra aynı yazarlar tarafından tablo içerisindeki sloganlar ayrı bir şekilde teker teker incelenerek temalar oluşturulmuş ve sonrasında kategori ve kodlar belirlenmiştir. Ardından yazarlar bir araya gelmiş ve oluşturdukları temaları, kategorileri ve kodları karşılaștırmışlardır. Karşılaştırma sonucunda \%87'lik bir uyuma ulaşılmış ve çalışmanın güvenilirliği sağlanmıștır. Yazarların ulaştığı ortak sonuca göre İnsan, Kurum, Duygu, Sistem, Türkiye ve Zaman olmak üzere toplam altı tema saptanmış ve 908 kodlama yapılmıștır. Bu kodlamalarda insan temasında: 206; kurum temasında: 56; duygu temasında: 226; sistem temasında: 71; Türkiye temasında: 253; zaman temasında: 96 kodlama oluşturulmuştur. Kodlama sonunda elde edilen modeller aşağıda yer almaktadır.

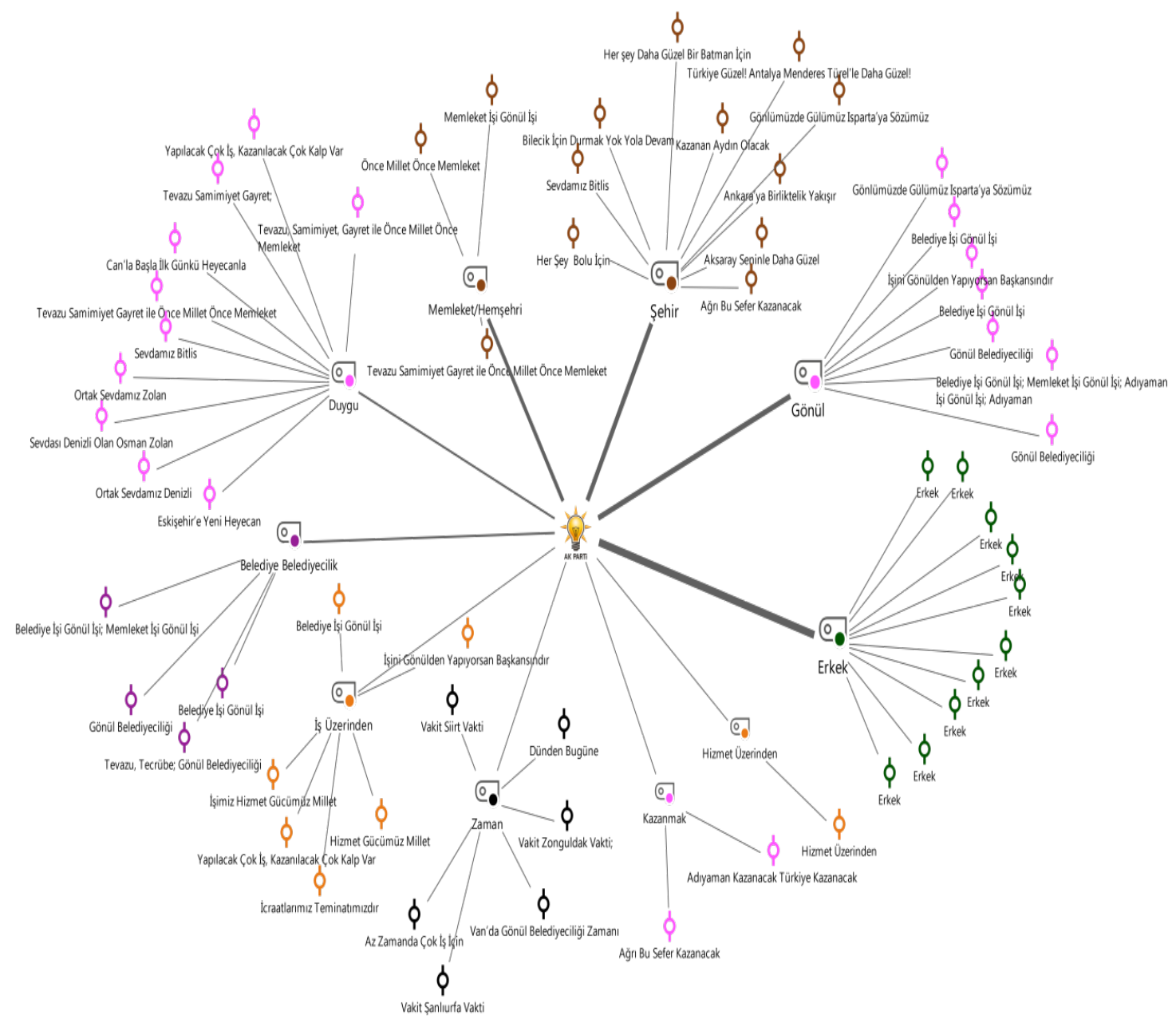

Şekil 1. Ak Parti Tek - Vaka Modeli

Ak Parti'nin tek vaka modelinde toplam 274 kod üzerinden değerlendirme yapılmıștır. Ak Parti'nin tek vaka modeline bakıldığında en fazla vurgunun Türkiye (92 kod), ve duygusal kelimeler (77 kod) olmak üzere iki başlıkta toplandığı görülmektedir. Ak Parti'nin 74 sloganındaki Türkiye temasında şehir isimleri, şehir kodlaması ile 52 kez 
kodlanmıştır. Aynı temada geçen Memleket kategorisinde ise 40 kez kodlama yapıldığı görülmüștür. Duygu temasında ise en fazla vurgu "gönül" kodunda (55) yapılmıștır. Bunun nedeni Ak Parti'nin "gönül" kelimesini ana slogan içerisinde kullanmasıdır. Analizde kurum temasında belediye/belediyecilik (17) başlığı önemli bir kategori olarak dikkat çekmektedir. Ayrıca Sistem (7), Zaman (7) temalarının en az kodlanan başlıklar olduğu görülmüştür. Ek olarak adayların cinsiyetlerine bakıldığında, İnsan temasında erkek (72) ve kadın (1) kategorilerinde, erkeklerin açık bir şekilde daha fazla olduğu saptanmıştır.

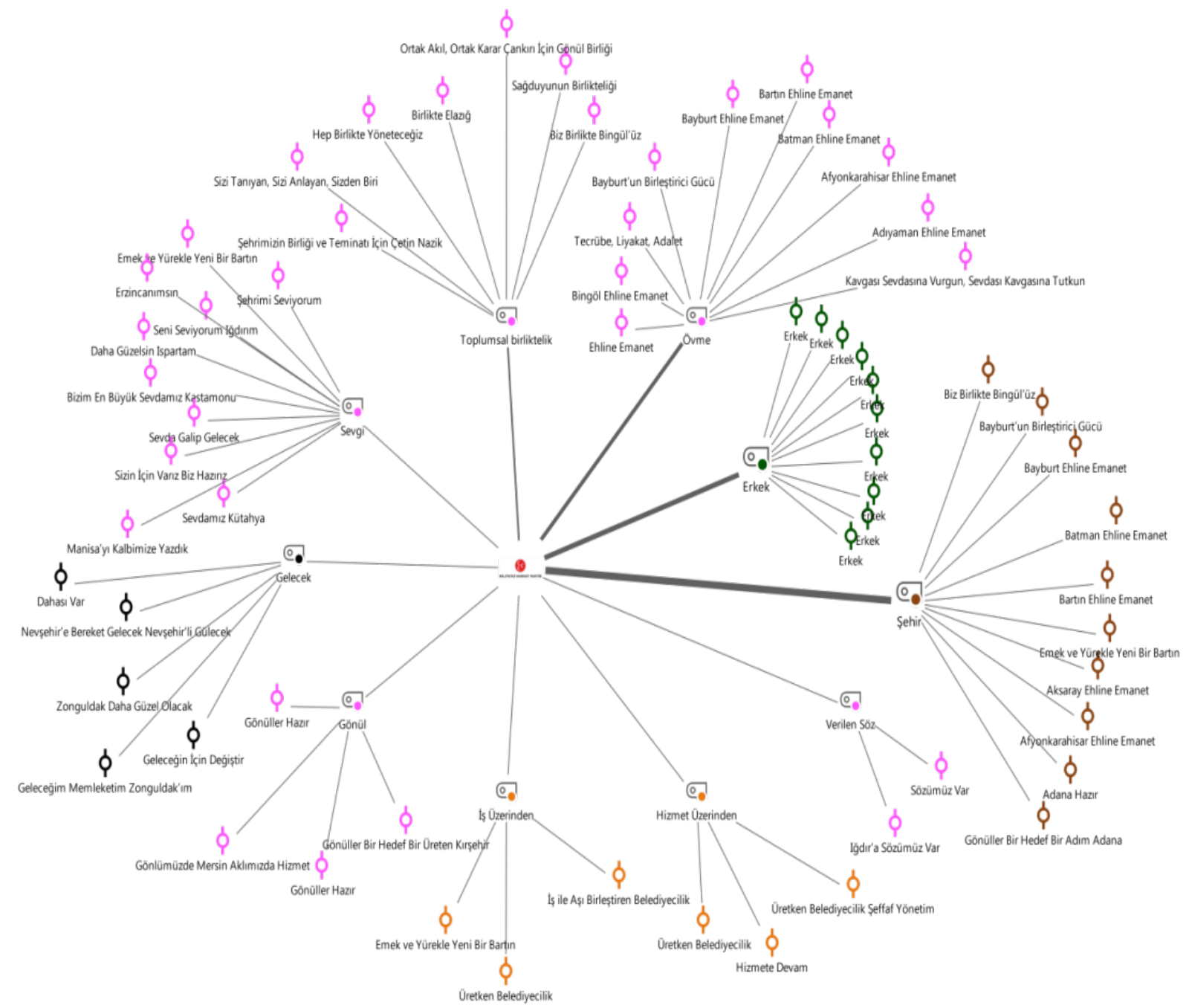

Şekil 2. Milliyetçi Hareket Partisi Tek - Vaka Modeli

MHP'nin tek vaka modelinde toplam 165 kod üzerinden değerlendirme yapılmıștır. En fazla vurgunun Türkiye (53 kod) ve duygu (övme 28 kod, toplumsal birliktelik 16 kod) olmak üzere iki temada yapıldığı görülmektedir. MHP’nin 85 sloganındaki Türkiye temasında en fazla şehir kategorisi şehir isimleri ile $52 \mathrm{kez}$ kodlanmıştır. Toplam 63 koddan oluşan duygu temasında en fazla kodun övme (28), toplumsal birliktelik (16) ve sevgi (11) ile ilgili olduğu görülmektedir. 7 kodun bulunduğu sistem temasında hizmet ve iş üzerinden kodlamaya örnekler bulunmaktadır. Zaman temasında yalnızca 5 kod sloganlarda yer alabilmiştir. MHP'nin kurum temasında kodlanacak herhangi bir veriye rastlanmamıștır. Ek olarak adayların cinsiyetlerine bakıldığında, İnsan temasında yer alan erkek (35) ve kadın (2) kategorilerinde, erkeklerin açık bir şekilde daha fazla olduğu saptanmıştır. 


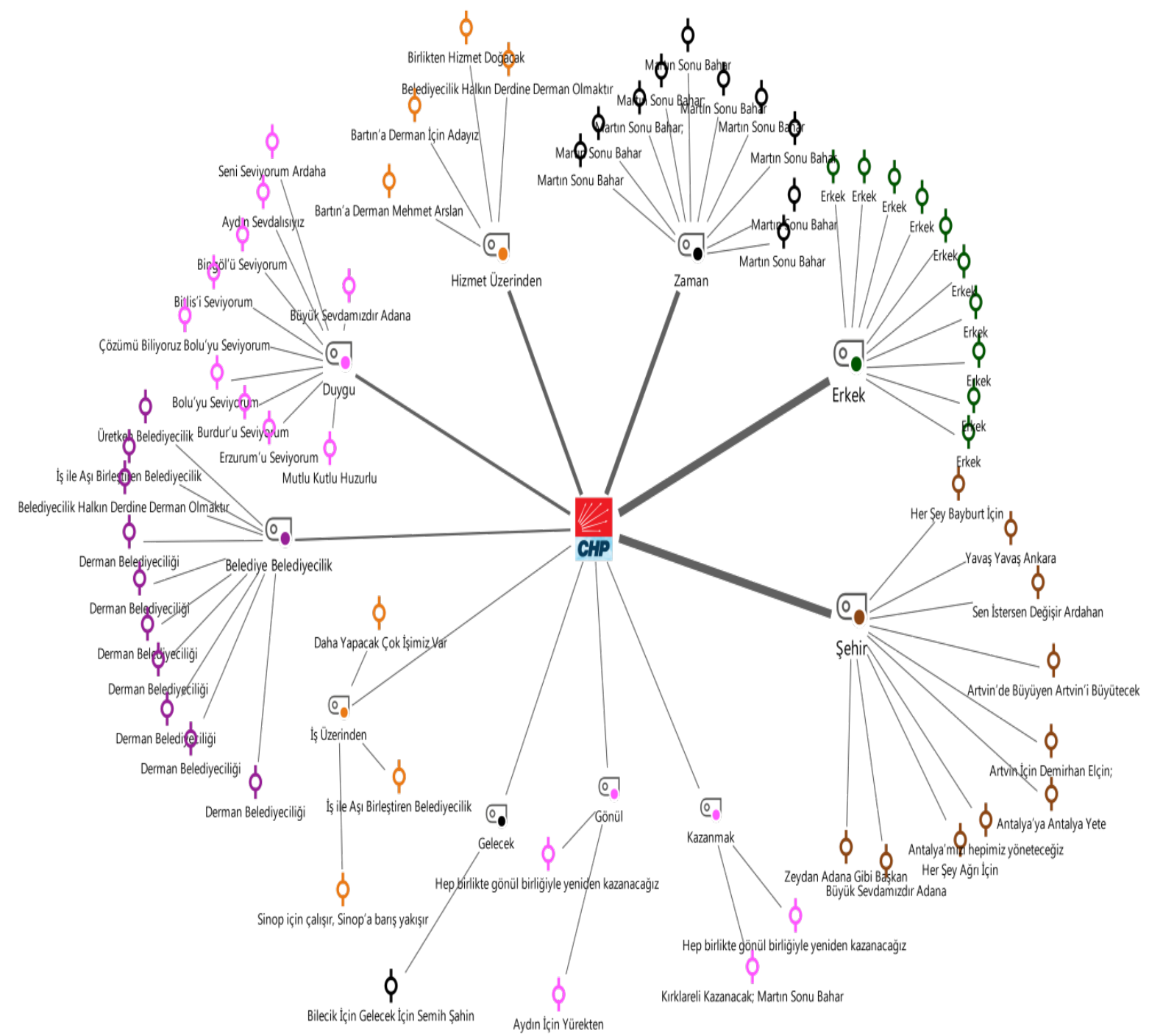

Şekil 4. Cumhuriyet Halk Partisi Tek - Vaka Modeli

CHP'nin tek vaka modelinde toplam 221 kod üzerinden değerlendirme yapılmıştır. En fazla vurgunun Türkiye (53 kod), zaman (36 kod) ve sistem (30 kod) olmak üzere üç temada yapıldığı görülmektedir. CHP'nin 57 sloganındaki Türkiye temasında en fazla şehir kategorisi șehir isimleri ile (52) kodlanmıștır. Ek olarak yalnızca 1 tane Türkiye kodu bulunmaktadır. Zaman temasında (39) geçmiş, bugün ve gelecek zaman kodları ele alınmıştır. Toplam 27 koddan oluşan duygu temasında en fazla kodun genel duygu kelimeleri ile (23) ilgili olduğu görülmektedir. Kurum temasında ise belediyecilik kategorisinde 19 kodlama yapıldı̆̆ Ek olarak adayların cinsiyetlerine bakıldığında, İnsan temasında yer alan erkek (52) ve kadın (1) kategorilerinde, erkeklerin açık bir şekilde daha fazla olduğu saptanmıştır. 


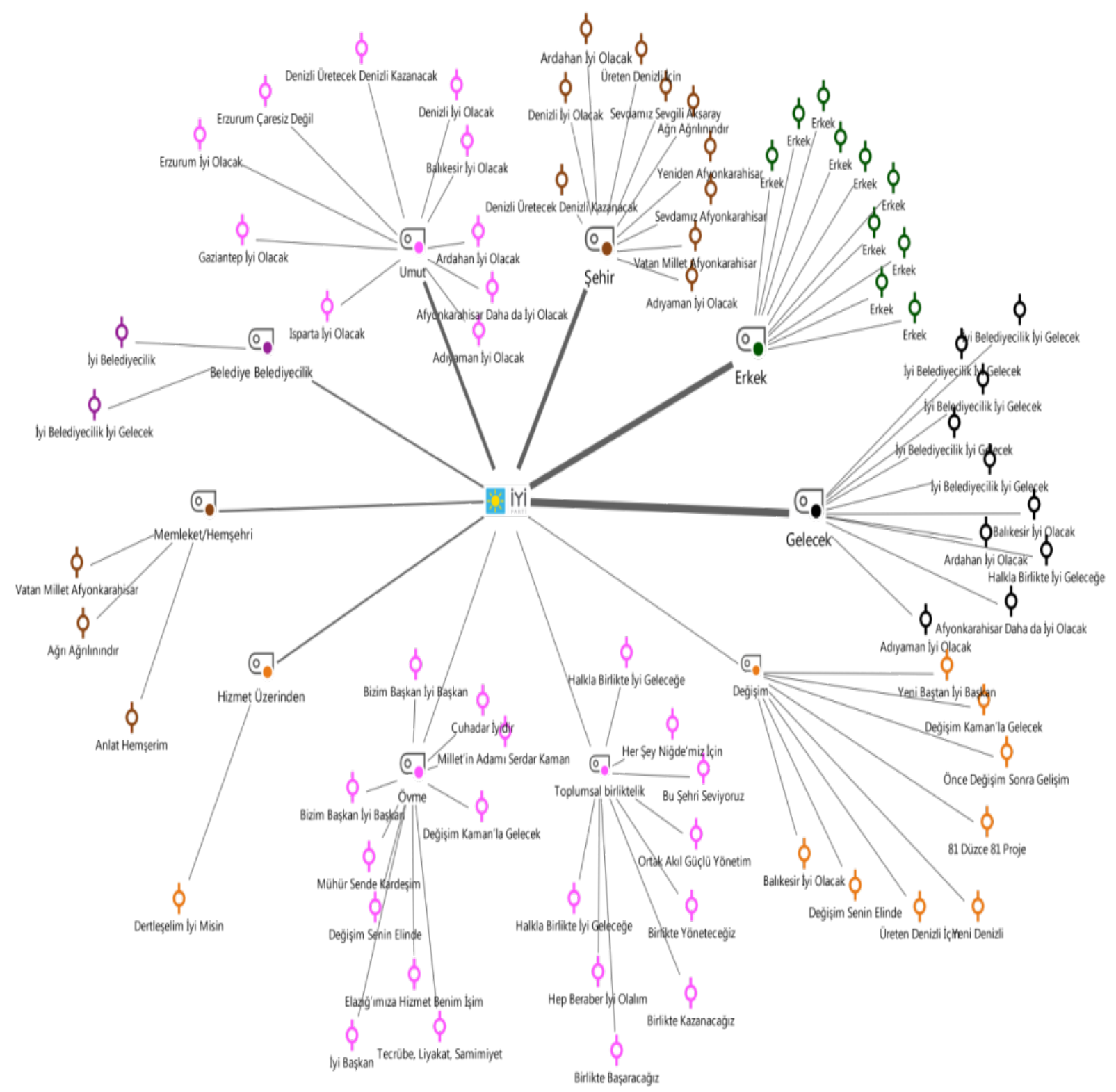

Şekil 5. IYİ Parti Tek - Vaka Modeli

IYYI Parti'nin tek vaka modelinde toplam 248 kod üzerinden değerlendirme yapılmıştır. IYYI Parti'nin 103 sloganındaki zaman teması çerçevesinde gelecek kategorisine (45) yer verildiği görülmektedir. Türkiye temasında şehir (37), memleket/hemşehri (17) kategorileri en fazla kod alan veriye sahiptir. Duygu temasında umut (29), övme (12) ve toplumsal birliktelik (19) kategorileri en fazla kod alan başlıklar olmuştur. Sistem teması içerisinde ise hizmete yönelik (16) ve değişime yönelik (8) kodlamalar en fazla değer alan başlıklardır. İYI Partinin kurum teması çerçevesinde belediye/belediyecilik ile ilgili (20) kodlarının bulunduğu da görülmektedir. Ek olarak adayların cinsiyetlerine bakıldığında, İnsan temasında yer alan erkek (41) ve kadın (2) kategorilerinde, erkeklerin açık bir şekilde daha fazla olduğu saptanmıştır. 
Tablo 1. Kod Sistemi ve İttifaklara Yönelik İki Vaka Modeli Klyaslaması

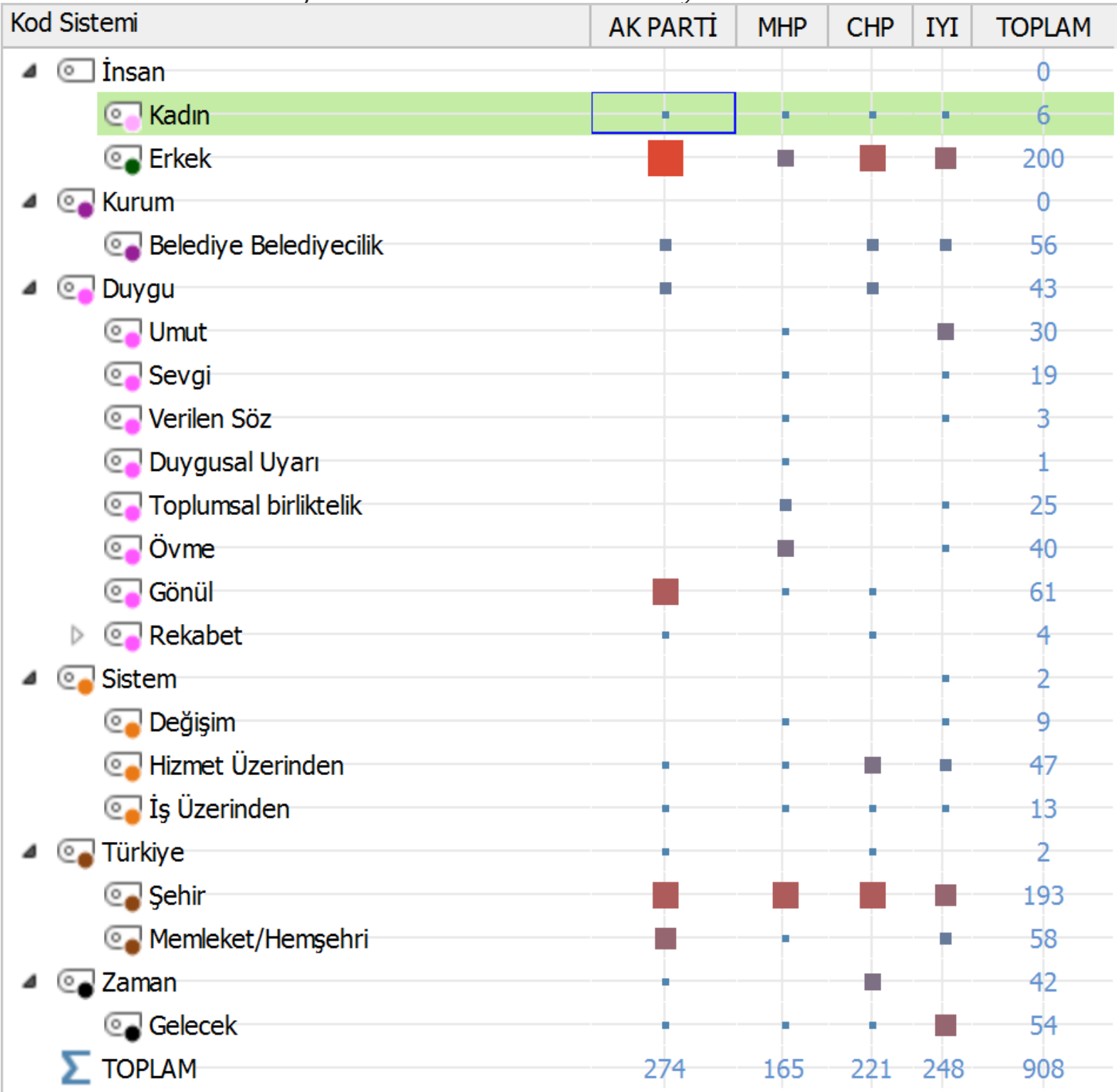

Yukarıdaki kod sistemine bakıldığında tüm partilerde erkek adayların kadın adaylardan çok daha fazla olduğu görülmektedir. Kod sistemi üzerinde en fazla yoğunluğun AK Parti'de olduğu görülse de bu yoğunluğun aday sayısıyla ilgili olabileceği göz önünde bulundurulmalıdır. Kurum temasında belediye/belediyecilik kategorilerinde MHP hariç diğer tüm partilerin benzer bir kullanım yoğunluğu görülmektedir. MHP'nin bu durumunun aday sayısı ve övme kategorisindeki içeriğe ağırlık vermesi nedeniyle olduğu düşünülmektedir. Duygu temasında AK Parti'nin gönül, MHP'nin övme ve toplumsal birliktelik, İYI Parti'nin umut kategorilerinde yoğunluğa sahip olduğu görülmektedir. CHP'nin ise duygu kategorisinde açık bir şekilde öne çıkan herhangi bir başlığı bulunmamaktadır. Sistem temasında CHP ve IYİ Partinin yoğunluğu göze çarpmaktadır. Diğer iki parti ise az sayıda olmak üzere benzer yoğunluktadır. Türkiye teması çerçevesi Şehir ve Memleket/Hemşehri kategorilerinde en fazla AK Parti'nin yoğunluğu görülmektedir. AK Parti, MHP ve CHP'nin şehir kategorisinde benzer yoğunluğa, İİ Parti'nin ise bu yoğunluğa yaklaşık bir içeriğe sahip olduğu görülmektedir. Memleket/ Hemşehri kategorisinde sırasıyla AK Parti, IYII Parti ve MHP'nin yoğunluğa sahip olduğu görülmektedir. Bu kategoride CHP'nin herhangi bir yoğunluğu bulunmamaktadır. Zaman 
temasında İYI Parti'nin gelecek kategorisinde CHP'nin ise doğrudan zaman temasında yoğunluğu görülmektedir. Diğer iki partinin az sayıda yoğunluğu saptanmıștır. Özetle tüm partilerin erkek adaylara, AK Parti ve MHP'nin duygusal içeriğe, CHP ve İYİ Parti'nin hizmet ve zaman/gelecek kategorilerine ağırlık verdiği görülmektedir. Dört Partinin de sloganlarında şehirleri öne çıkardığı, fakat memleket/hemşehri kategorisinde en fazla AK Parti'nin vurgu yaptığı görülmektedir.

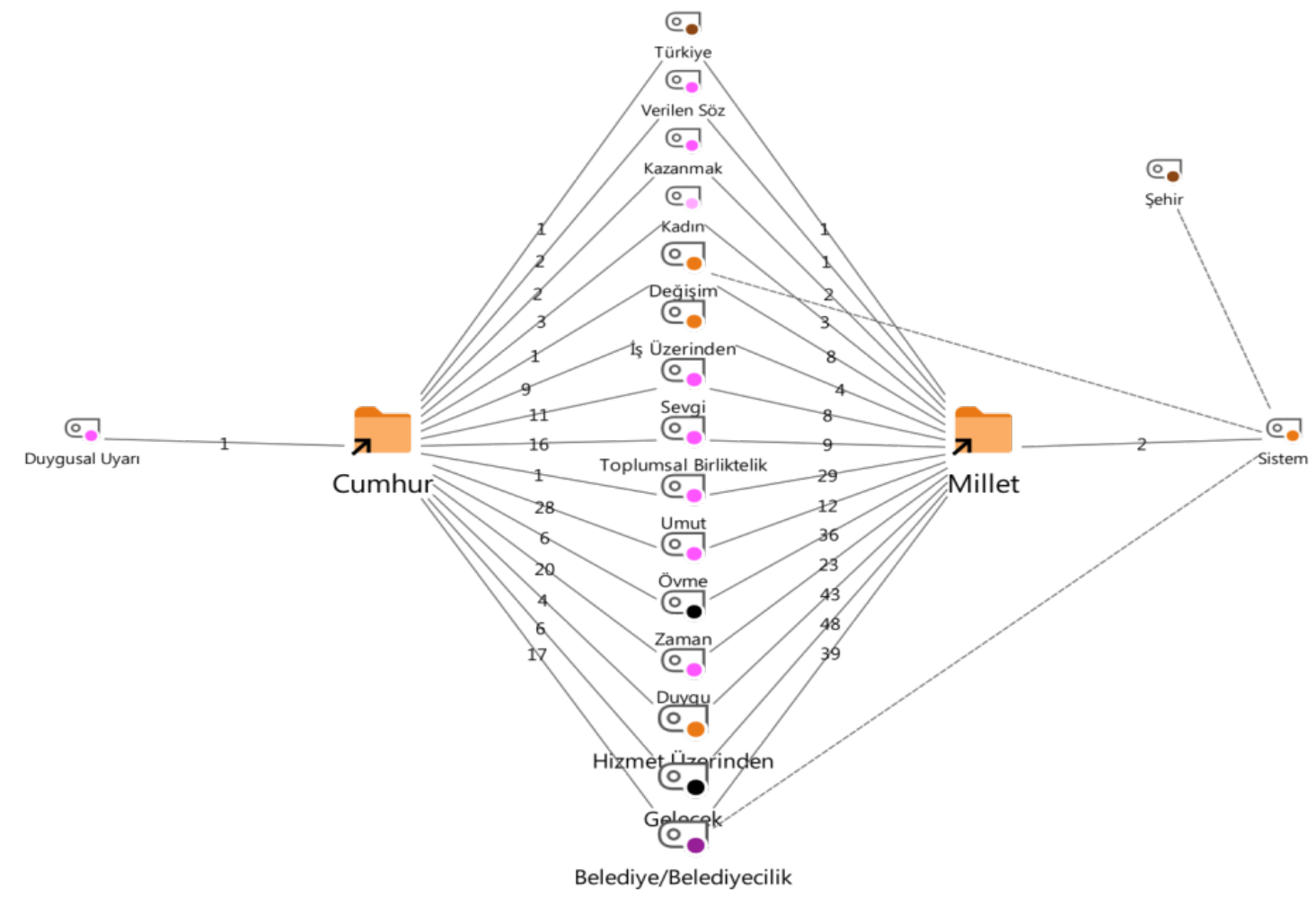

Şekil 6. Cumhur ve Millet İttifakına Yönelik İki - Vaka Modeli

Cumhur ve Millet ittifaklarına yönelik iki vaka modeline bakıldığında Cumhur İttifakının sloganlarında; yapılan iş, sevgi, toplumsal birliktelik, övme kategorilerinin öne çıktığ görülmektedir. Millet ittifakının sloganlarında ise değişim, zaman, duygu, hizmet, gelecek ve belediye/ belediyecilik kategorilerinde açık bir şekilde daha fazla kavram içeriğine yer verdiği görülmektedir. Türkiye, verilen söz, kazanmak, kadın, duygu kategorilerinde ise ittifakların birbirlerine dikkate değer bir üstünlükleri bulunmamaktadır. Ayrıca Cumhur İttifakının duygusal uyarıda farklı bir kategoriye sahip olduğu, Millet İttifakında sistemle ilgili ve bu sistemin belediye/belediyecilik, değişim alt başlıklarında Cumhur ittifakı ile ayrı bir bağlantısı olduğu görülmektedir. Bu bağlantı farklı kategorilerin de alt başlıklarda diğer kategorilerle açıklanabileceğini göstermektedir. Ayrıca Millet İttifakındaki sistem başlığı içerisinde bulunan "şehir" kategorisinin ayrıca açılmış olması, "Üreten Denizli İçin" sloganıyla bu kategoriye Cumhur İttifakından daha farklı bir vurgu yapıldığını göstermektedir.

\section{Tartışma ve Sonuç}

Sloganların, siyasal iletişim sürecinde işlerliği ve ideolojik bir söylem olarak başarı sağlama noktasındaki aktarımı birçok akademik çalışmada incelenmiş ve önemli noktalar saptanmıştır. Örneğin, Brandi, (2007) İrlanda özelinde ele aldığı ideolojik çözümlemesinde; ideolojinin hem sosyolojik hem de politik anlamda kullanılan ve sosyal hayatta farklı algılama biçimleriyle ele alınan bir kavram olduğunu dile getirmektedir. Bununla birlikte bir sosyal yapıdaki kültürel ve siyasi anlamda kabul görme niteliği de 
taşıdığını; sadece baskı kelimesinin bir karşılığı olmadığını, aynı zamanda başka gözle bakabilme, farklı türden algıya sahip olma ve insan iradesi doğrultusunda algılanan bir olgu olduğunu vurgulamıştır. Damlapınar ve Balcı (2014) siyasal iletişim süreciyle ilgili çalışmalarında, politik sloganların insanların zihinlerinde belirli algılar yaratarak onları istenen yönde davranışa yönlendirdiğini tespit etmiştir. Ahlers ve Schubert (2009) politik slogan kavramı üzerine odaklandıkları çalışmalarında; politik sloganların seçim dönemlerindeki etkisinin fazla olduğunu ve insanları belirli ideolojiler doğrultusunda hareket ettirmede etkili olduklarını belirtmiştir. Bunun yanı sıra Bartenstein (2010) slogan kullanımını derinlemesine ele aldığı çalışmasında; sloganların içinde bulunulan mevcut durumlarla ilişkilendirilerek hazırlandığını, bu doğrultuda seçim sloganları hazırlanırken akla uygun olmasına ve kullanım olanağı sağlamasına bakıldığını vurgulamaktadır. Aynı zamanda Leith (2004) gizlilik değerlendirmesi bağlamında özel bir olgu olarak slogan kavramını değerlendirdiği çalışmasında; siyasi arenada kullanılan sloganların günün şartlarına uygun olarak hazırlanması gerektiğini savunmakla birlikte; bu çerçevede sosyal mecrada sergilenen sloganların içerik olarak özellikle beklentilere seslendiğini belirtmektedir. Bununla birlikte Temel (2020) 31 Mart 2019 seçimlerine yönelik, Türkiye'deki genç nüfusun medya kullanım pratiklerine ilişkin gerçekleștirdiği çalışmasında; özellikle internet odağında hazırlanan mesajların gençlerin siyasal katılım davranışını belirlemede daha başarılı olduğunu, politik aktörlerin yeni medya çerçevesindeki başarılı siyasal iletişim çalışmalarının önemli getirileri olabileceğini tespit etmiştir.

31 Mart 2019 yerel seçimlerinde siyasi parti ve adaylar, farklı içeriklerle hazırladıkları sloganlarını seçmenlere farklı kanallarla aktarmışlardır. Bununla birlikte, Türkiye'de seçimlere ittifaklar içerisinde gidilerek siyasi partilerin ve adayların değişik stratejilerle seçmenlere seslendiği görülmüştür. Bu doğrultuda Cumhur İttifakı içerisinde yer alan Ak Parti ve Milliyetçi Hareket Partisi, Millet İttifakı içerisinde yer alan Cumhuriyet Halk Partisi ve İyi Parti kendi ideolojilerindeki söylemlerini, adaylara sunulan sloganlarla bütünleştirerek seçmene sunmuştur. Aynı zamanda siyasi partiler ve adaylar seçim dönemi boyunca ideolojik söylemleri dâhilinde hazırladıkları sloganlarını her türlü platformda yayınlayarak etki yaratmaya çalışmıştır. Seçim dönemlerinde ideolojik sloganlardan, seçmenlerin algılarında etki bırakmak amacıyla yararlanılmaktadır. İttifakların sloganları üzerine yoğunlaşan bu çalışmada partilerin sloganlarının insan zihnine hitap edecek şekilde hazırlandığı, uzunluğu ya da kısalığı noktasında ise adayların kişisel tercihlerinin belirleyici olduğu saptanmıștır. Sloganların sunumlarının basit ve işlevsel olduğu, içeriklerinde ise yapılan ya da yapılacak projelerle ilgili bildirimlerin yer aldığı görülmektedir. Sloganların sadece açık hava platformları, basın, televizyon gibi platformlara ara mesaj olarak sıkıştırılmadığını; her bir parti ve adayın dijital mecrada içerik ürettiğini ve seçmenlere seslendiğini görmek de mümkün olmuştur.

Mart 2019 Türkiye yerel seçimlerinde mecliste bulunan dört partinin 81 ilde yayınladıkları sloganlarının tek vaka ve iki vaka modellerine göre değerlendirmeleri yapıldığında aşağıdaki sonuçlara ulaşılmıştır. Ak Parti tek vaka modeli dikkate alındığında 274 kodun kullanıldığı ve en fazla vurgunun 92 kod ile "Türkiye" üzerine yapıldığı görülmektedir. En az vurgu ise 7'şer kod ile "zaman" ve "sistem" temaları üzerinedir. MHP tek vaka modeli incelendiğinde, 165 kod kullanılmış olup, Ak Parti gibi en fazla vurgunun 53 kod ile "Türkiye" temasında ve en az vurgunun ise 5 kod ile "zaman" temasında olduğu ortaya koyulmuştur. CHP tek vaka modelinde ise 221 kod kullanılmış olup en fazla vurgunun "Türkiye"nin (53 kod) yanı sıra (Ak Parti ve MHP'nin tersine) "zaman" (36 kod) ve 
"sistem" (30 kod) temaları üzerine olduğu belirtilmiştir. Son olarak, İYI Parti tek vaka modeli değerlendirildiğinde 248 kod üzerinden ele alındığı ve en fazla vurgunun "zaman teması" üzerinde olduğu saptanmıştır. Partilerin tek vaka modellerinde "insan" temasında "adayların cinsiyetleri" dikkate alındığında dört partide de erkek adayların kadın adaylara göre sayıca çok fazla olduğu görülmüştür. Cumhur ve Millet ittifakına yönelik iki vaka modeline bakıldığında; Cumhur İttifakının sloganlarında "iş", "sevgi", "toplumsal birliktelik", "övme" kategorilerine yer verdiği görülmektedir. Millet İttifakının ise "değişim", “zaman”, "duygu”, "hizmet”, "gelecek" ve "belediye/belediyecilik" kategorilerini öne çıkardığı anlaşılmaktadır. Ayrıca "Türkiye”, "verilen söz”, "kazanmak", "kadın”, "duygu" kategorilerinde ise ittifakların birbirlerine yönelik dikkate değer bir farklılıkları bulunmamaktadır. Cumhur ve Millet ittifakının kesişen tema ve kodlarına bakıldı̆̆ında Türkiye, Verilen Söz, Kazanmak, Kadın, Değişim, İş, Sevgi, Toplumsal Birliktelik, Umut, Övme, Zaman, Duygu, Hizmet, Gelecek kavramları ile karşılașılmaktadır. Bu kavramların genel olarak birliktelik, duygusal içerik ve zaman ile ilgili olduğu görülmektedir. Dolayısıyla taraflarda bu stratejik tabanda içerik üretildiği söylenebilir.

Seçime giren ittifakların ideolojik söylemlerinde bazı farklı içerikler olduğu ve her bir siyasi parti ve adayın belirli temalarda birleștiği tespit edilmiştir. Parti ve adayların özellikle üzerinde durdukları temaların kendi ideolojilerini temsil ettiği söylenebilir. Bu doğrultuda her bir parti sahip olduğu ideolojiyi seçmenlere yansıtmıștır. Seçmenlerin algısına, kendilerinin belirledikleri söylem odağında seslenilerek başarının hedeflendiği görülmektedir.

\section{Kaynakça}

Ahlers, A. L., ve Schubert, G. (2009). "Building a new socialist countryside" - only a political slogan? Journal of Current Chinese Affairs, 38(4), 35-62.

Althusser, L. (2003). Ídeoloji ve devletin ideolojik aygıtları. (A. Tümertekin, Çev.) İstanbul: İthaki Yayınları.

Bartenstein, K. (2010). "Use it or lose it": An appropriate and wise slogan? Policy Options(July-August), 69-73.

Barthes, R. (1996). Çağdaş söylenler. (T. Yücel, Çev.) İstanbul: Metis Yayınları.

Berger, J. (1999). Görme biçimleri. (Y. Salman, Çev.) İstanbul: Metis Yayınları.

Bourdieu, P. (2000). Esquisse D’une théorie de la pratique Paris: Edition du Seuil.

Brandi, S. (2007). Unveiling the ideological construction of the 2004 Irish Citizenship Referendum: A critical discourse analytical approach. The Irish Migration, Race and Social Transformation Review, 2(1), 26-47.

Butler, P., ve Collins, N. (1994). Political marketing: Structure and process. European Journal of Marketing, 28(1), 19-34.

Carver, T. (1995). Ideology. T. Ball, R. Dagger, \& D. I. O’Neill içinde, Ideals and ideologies: A reader (s. 3-10). New York: Harper Collins.

Charaudeau, P., ve Maingueneau, D. (2002). Dictionnaire D'analyse du discours. Paris: Editions du Seuil.

Cone, S. (2006). Marketing campaigns: Getting the basics right. Director, 59(7), 33.

Çelik, N. B. (2005). İdeolojinin soykütüğü-1: Marx ve ideoloji. Ankara: Bilim ve Sanat Yayınları. 
Damlapınar, Z., ve Balcı, Ş. (2014). Siyasal iletişim sürecinde seçimler, Adaylar, İmajlar. Konya: Literatürk Academia.

Davenport, T. H., ve Beck, J. C. (2010). Dikkat ekonomisi. İş dünyasının yeni değerini anlamak. (S. Diktaş, Çev.) İstanbul: Starcom MediaVest Group (SMG) Turkey.

Drucker, H. M. (1974). The political uses of ideology. London: Barnes and Noble.

Eagleton, T. (2004). Kuramdan sonra. (U. Abacl, Çev.) İstanbul: Literatür Yayıncllık.

Eagleton, T. (2005). Ídeoloji. (M. Özcan, Çev.) İstanbul: Ayrıntı Yayınları.

Greimas, A. J. (1979). Sémiotique et sciences sociales. Paris: Editions du Seuil.

Gümüştekin, N. (2011). Anadolu ve diğer kültürlerde işaret ve simgelerde anlam. Balıkesir University Journal of Social Sciences Institute, 14(26), 103-117.

Johnson, C. (2013). Miktotarz-kısa yazma Sanatı. (H. Mesci, Çev.) İstanbul: Starcom MediaVest Group Turkey.

Krysinski, W., ve Krysinski, W. (1981). Carrefours de signes sur le roman. The Hague: Mouton.

Lanning, M. J., ve Michaels, E. G. (2000). A business is a value delivery system, delivering value to customers. McKinsey Quartely(June), 53-57.

Leith, P. (2004). “Use it or lose it": An appropriate and wise slogan? Belfast: Queen's University.

Lukacs, G. (2006). Tarih ve sınıf bilinci. (Y. Öner, Çev.) İstanbul: Belge Yayınları.

Maingueneau, D. (2007). Open Edition Journals. 08 01, 2020 tarihinde L'idéologie: Une Notion Bien Embarassante: http://contextes.revues.org/index189.html adresinden alındl.

Mardin, Ş. (2010). Ídeoloji. İstanbul: İletişim Yayınları.

McLuhan, M. (2002). Gutenberg galaksisi. (G. Ç. Güven, Çev.) İstanbul: Cogito.

Meriç, C. (1996). Ümrandan uygarlığa. İstanbul: İletişim Yayınları.

Örs, B. H. (2009). Postmodern dünyada ideolojinin dönüşümü. İ. Ü. Siyasal Bilgiler Fakültesi Dergisi(40), 1-12.

Özkan, N. (2004). Türkiye ve dünyadan örneklerle seçim kazandıran kampanyalar. İstanbul: MediaCat Kitapları.

Öztürk, M. (2014). Seçim sloganlarının seçmen hissiyatına tercüman olma yarışı: 30 Mart 2014 seçimlerinin bir analizi. FSM İlmi Araştırmalar İnsan ve Toplum Bilimleri Dergisi, 4, 91-109.

Power, D. J. (2016). Big brother can watch us. Journal of Decision Systems, 25(1), 578-588.

Pratkanis, A., ve Aronson, E. (2008). Propaganda çağı iknanın gündelik kullanımı ve suistimali. İstanbul: Paradigma Yayınları.

Rıfat, M. (2013). Açıklamalı göstergebilim sözlüğü. İstanbul: İş Bankası Yayınları.

Rivkin, S., \& Sutherland, F. (2011). Bir marka adı yaratmak. (U. Mehter, \& D. Arı, Çev.) İstanbul: Brand Age Yayınları.

Ryan, M., ve Kellner, D. (2016). Politik kamera. (E. 2016, Çev.) İstanbul: Ayrıntı Yayınları. 
Sapiro, G. (2007). Open Edition Journals. 08 01, 2020 tarihinde Pour Une Approche Sociologique Des Relations Entre Littérature Et İdéologie: http://contextes. revues.org/index165.html adresinden alındı.

Sharkansky, I. (2002). Slogan as policy. Journal of Comparative Policy Analysis, 4(1), 7593.

Temel, F. (2020). Genç nüfusun seçim dönemlerinde medya kullanımı: Türkiye 31 Mart 2019 yerel seçimleri. Erciyes İletişim Dergisi, 7(2), 989-1010.

Yeygin, D. A. (2012). Mekanikleşen birey: Arçelik örneğinin R. Barthes'a göre çözümlemesi. The Turkish Online Journal of Design, Art and Communication TOJDAC, 13-21.

Yıldız, F. U., \& Günay, V. D. (2011). Yazınsal söylemin ideolojik boyutu. Synergies Turquie(4), 153-167.

Ylldırım, A., \& Şimşek, H. (2018). Sosyal bilimlerde nitel araştırma yöntemleri. Ankara: Seçkin Yayıncılık.

Yıldırım, İ. E. (2015). İstatiksel araştırma yöntemleri ve su tüketim bilinci üzerine bir kamuoyu araştırması - araştırma tasarımı/örnekleme/veri toplama teknikleri. Ankara: Seçkin Yayıncılık.

Zizek, S. (2011). İdeolojinin yüce nesnesi. (T. Birkan, Çev.) İstanbul: Metis Yayınları. 


\title{
Thinking on the Slogan as an Ideological Discourse: A Comparative Analysis on the Party Slogans Used in the March 2019 Local Elections in Turkey
}

\author{
Mikail Batu (Assoc. Prof. Dr.) \\ Akan Yanık (Assoc. Prof. Dr.) \\ Onur Tos (Lect.)
}

\section{Extended Abstract}

The explanation and use of ideology in terms of countries and nations and its reflection to the public are dated back to old times. However, it can be said that the emergence of ideology is in parallel with the cooperation efforts of people and their management activities. The ideology with the fact of perceptual persuasion constitutes the basis and reason for the cooperation of people with common view, the mechanism of their mobilization and the exhibition of desired behaviors. In other words, the term of ideology, which the political party, leader and candidate in the election race effectively uses during the election, is the main reason for the perceptual movement and voting behavior in the minds of the voters.

It is possible to say that political parties conduct campaigns in parallel with their ideologies during the election, and candidates act by creating different types of political communication contents with the ideology of the party leaders. Political parties, leaders and candidates use different strategies and tactics to adopt their ideology to voters and lead them to vote in the desired direction throughout the campaign. The use of slogans, emphasizing these slogans continuously with their political advertising contents and using different promotion and message transfer platforms as a means of persuasion are some of them.

Slogans, which are of great importance in the elections, are a style of discourse that is used to spread ideology from the past to the present. At the starting point of this discourse is the idea to mobilize the electorate and win the elections. Each slogan is created in parallel with the current position, ideology and stance of the political party, leader and candidate. The exhibition of slogans is made possible by using open air, social media advertisements and different mass media. The political party, leader and candidate, effectively using these platforms, manage to be permanent in the minds of the voters.

The idea of achieving the current power, gaining a large number of municipalities or having a large number of deputies in the Turkish Grand National Assembly constitute the basis of the political communication activities of the political party, leaders and candidates. In this context, several activities are conveyed with discourses and supported by slogans, and it is possible with the effective reflection of the ideology. When the success of the messages reaching to electorate will be more than the messages reaching them less, it is important to note that the highly conveyed ideological discourses are one of the key points of success.

Several political parties and candidates competed in the Turkish local elections of 2019 that were held on Sunday 31 March 2019. The competing parties were not just political parties and candidates in the Turkish Grand National Assembly. Particularly in this election, it 
is noteworthy that an election race occurred in the focus of alliances. In this election, alliances are grouped as People's Alliance and Nation Alliance. While People's Alliance included the Justice and Development Party (AKP) and the Nationalist Movement Party (MHP), Nation Alliance included the Republican People's Party (CHP) and the Good Party (IYI). Each political party entered the election race in the specific provinces by taking the opinions of its leaders. With the alliances between the parties, a single party competed in specific provinces, whereas each party showed its own candidate in other provinces. This research is prepared for the analysis of slogans used by the political parties, leaders and candidates of Nation Alliance and People's Alliance during the election on Sunday 31 March 2019 that was the competition of alliances. In this context, content analysis and descriptive analysis were used for the slogans of each political party, leader and candidate in the alliance in parallel with their current ideologies. In the analyses, it was determined as a basic problematic to reveal which concepts become similar and differ in the slogans used by candidates of the alliances to persuade the voters. As a result of the analyses, it was determined that the parties of the alliances put different codes during the election and called the voters with these discourses. As a result of the analysis, the codes of heart and hope were determined as the main codes that became prominent in slogans. Also, it was observed that the system is explained over the provided service, the city was frequently emphasized and the future became prominent in slogans. In addition, it was determined that the alliances called the perception of the voters with different discourses from other parties and in parallel with the ideologies of their parties.

Keywords: Public Relations, Ideology, Election Slogan, People’s Alliance, Nation Alliance.

Bu makale intihal tespit yazılımlarıyla taranmıştır. Intihal tespit edilmemiştir.

This article has been scanned by plagiarism detection softwares. No plagiarism detected.

Bu çalışmada "Yükseköğretim Kurumları Bilimsel Araştırma ve Yayın Etiği Yönergesi" kapsamında uyulması belirtilen kurallara uyulmuştur.

In this study, the rules stated in the "Higher Education Institutions Scientific Research and Publication Ethics Directive" were followed. 